\title{
卷酸言
}

\section{非常識への挑戦から新たなサイエンス の扉を開け！}

国立研究開発法人医薬基盤・健康 $\cdot$ 栄養研究所 医薬基盤研究所長

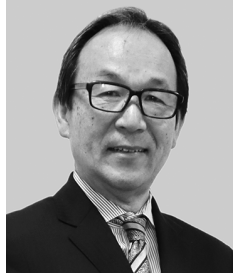

私は九州大学大学院薬学研究科修士課程を修了後, 企 業に就職し 40 年近くに亘って医薬品の研究開発に携 わってきました。大学院では, 故兼松顕先生の薬品製造 化学教室に入り先生から化学実験の重要性についてご指

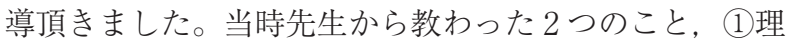
論科学を化学実験で検証すること, (2)生物現象を化学実 験で解明すること，このことが私の 40 年間に亘る創薬 研究の原点になっています。当時脚光を浴びていた，フ ロンティア軌道理論を化学的に検証する分子設計の研究 は今でも鮮明に覚えています。企業に入社後, 創薬研究 に携わり化学と生物の両方に興味を持つようになったの は, 化合物の構造と生理活性や副作用の相関性を確認し ながら生物機能の解明を進める中で培われてきたと思い ます。創薬研究における分子最適化の目的は医薬品とし て望ましいプロフィールの化合物を見出すことですが, それを検証し解明していくためのドラッグデザインは正 に創薬研究の醍醐味の一つです。“デザインした化合物 が，なぜそのような生理活性を示すのか？”私の興味は 化合物が体内で標的分子に出会い, 双方が相互作用して 起こす生物現象に徐々に広がっていったように思います。

21 世紀に入ってライフサイエンスの領域でとても大 きな出来事がありました。1990 年に米国が 30 億ドルを 投じてヒトの全遺伝子解析プロジェクトを開始し，2003 年 4 月にヒト全ゲノム解読に成功したことです。当時は 国家の威信を掛けて日本や欧州諸国の研究者もしのぎを 削っていました。この全ゲノム解析の大きなボトルネッ クになっていたのが解読スピードです。解読スピードを 上げるために大きく貢献した技術がセレラ社の開発した ゲノム高速解析法(ショットガンシークエンス法)です。こ の解析技術によってゲノムサイエンスの屝が開かれ，今 では世界中でライフサイエンス研究に利用されています。

ところで, 同じ 2003 年に世界を驚愕させる感染症が 複数発生したことも強く記憶に残っています。アジアを 中心に 29 の国と地域に拡大した SARS やヒト感染が確 認された鳥インフルエンザウイルスの発生です。その時 にはまさか 17 年後の今になって新たなコロナウイルス によるパンデミック感染が世界中で起きるとは予想だに
していませんでした。

さて，ヒトゲノムの解読によって創薬研究の方法論が 急速に変わってきました。製薬企業が長年に亘って行っ てきた低分子化合物ライブラリーから医薬品候補化合物 を見出すスクリーニング創薬はもはや創薬研究の主流で はなく, 現在は疾患患者の遺伝子情報から治療薬を見出 すゲノム創薬に大きく舵が切られています。その結果, 世界の売上げトップ 10 をバイオ医薬品が独占すること になりました。また医療手法のパラダイムシフトも急速 に進んでおり, 個別化医療, 細胞医療, デジタル医療, $\mathrm{AI}$ 医療など医療の多様化によって従来の医療のやり方 だけでは通用しない混迷の時代になってきています。

さて，学生の頃に恩師に教わった生物現象を化学で解 明することの重要性を, 最近の抗体医薬の一つである ADC “Antibody Drug Conjugate”から改めて感じてい ます。注目のモダリティー分子となった ADCの主役は 抗体なのか？ ペイロードと称する化合物なのか？ と いう質問に対して「主役は両分子であり, 生物分子(抗 体) と合成化合物(ペイロード)の融合が価值ある新規な モダリティーの扉を開けたのだと」私は答えます。正に 化学と生物の融合により新たなサイエンスの屝が開かれ ました。これから新しいモダリティー分子による医薬品 の創製が活発になることを期待しています。

最後に, 新しい技術革新を可能とするサイエンスの扉 を開くためには発想の転換，すなわち，将来を予見して “イノベーション”を起こしていくことが必要になりま す。イノベーションを実現するための重要な要件の一つ が“人”です。特に, イノベーションを先導する研究者の 役割は非常に大きいと思っています。残念なことは優れ た発想がその時には優れた発想であることに気づかずゴ ミ箱に捨てられることです。人の常識が時に大きな過ち を犯してしまいます。常識や固定観念にとらわれない研 究者の輩出が重要です。常識の分かる人は非常識も理解 できます。研究者としてイノベーションを起こしていく ために, “バカになって非常識に挑戦する”ことが重要で はないでしょうか?

(2021 年 3 月 5 日受理) 